\title{
大規模パブリックコメントの論点把握に対する テキストマイニングの有用性の検討
}

\author{
岩見 麻子 1 ・宮下 知己 $2 \cdot$ 井手 慎司 3 \\ 1 正会員 愛知工業大学PD研究員 地域防災研究センター ( \\ E-mail: iwami-a@aitech.ac.jp \\ 2非会員 滋賀県立大学学士課程 環境科学部環境政策・計画学科 ( \\ 3非会員 滋賀県立大学教授 環境科学部環境政策・計画学科 (†522-8533 滋賀県彦根市八坂町2500)
}

\begin{abstract}
本研究では，国家戦略室が2012年に実施した「エネルギー・環境に関する選択肢に対する御意見の募集」 を事例として，大規模パブリックコメントに提出された意見から主要な論点を把握し，論点間の関係性を 可視化するための分析手法としてテキストマイニングの有用性を検討するとともに，問題点や課題を明ら かにすることを試みた。その結果，提出された意見から「エネルギー政策の転換」や「放射性廃棄物の処理」 など17の論点を特定，論点間の関係性を可視化することができ，手法として有用である可能性を示すこと ができた．また，極端に類似した大量な意見群がある可能性や，比較的言及の少ない論点を特定できる対 象語を客観的に抽出する手法を検討する必要性などの課題も明らかにすることができた.
\end{abstract}

Key Words: big data analysis, network analysis, citizen participation, energy policy

\section{1. はじめに}

近年，行政の意思決定プロセスへの住民参加の必要性 が増してきている，住民参加の手続きとしては，意見聴 取会や住民投票，世論調査，パブリックコメント(以下， $\mathrm{PC}$ ) など数多く存在するが, 特に PC制度は一般市民の意 見を広く求めることができる制度として定着しつつある.

しかし, PCは世論調查などと異なり一般的に自由記述 によるものであることから，客観性を担保した論点の把 握や，同じ論点に言及している意見数の集計，論点間の 関連性など，その全体を概観することが困難である，そ のことも一因となり，提出された意見がどのように政策 に反映されたかが不透明であり，提出された意見に基づ く議論の展開など，発展的手法が見られず形骸化してい るなどの課題も指摘されている ${ }^{1)}$.

$\mathrm{PC}$ に関する既存研究としては，PC 募集時に提示され た資料の量や提出された意見への行政の対応を整理し， $\mathrm{PC}$ の課題を指摘したものりや，計画策定時における実施 状況や提出された意見数を把握することで現状を概観し たもの 2などがあるが，これらは提出された意見の内容 分析を行ったものではない. 内容にまで踏み込んで分析 を行った既存研究としては，庭園の保全および利活用に 関する PC を対象に，提出された意見やそれに対する行
政の回答を精査し, PCを活かした市民参加型の庭園管理 の今後の可能性を考察したもの ${ }^{3} や ，$ 国の第三次環境基 本計画策定に際して実施された PC から代表的な意見を 抽出し, 計画案本文中の該当箇所を紹介しながら意見の 内容を概説したもの 4,5)などがある. ただし，これらの研 究はいずれも意見を読み解く方法で分析した事例であり, $\mathrm{PC}$ に提出された意見数もそれが可能な数十件程度の小 規模なもの，もしくは寄せられた意見の一部を分析対象 としたものであった.

しかし近年，数万件を超える意見が提出されるような 大規模 PC も現れるようになってきた，たとえば環境省 が 2011年に実施した「動物取扱業の適正化について(案)」 には約 12 万件, 内閣官房国家戦略室(以下，国家戦略室) が 2012 年に実施した「エネルギー・環境に関する選択肢 に対する御意見の募集」には約 9 万件の意見が寄せられ た. しかし，このような膨大な数の意見を読み解き，論 点を把握し, 各論点の意見数や属性による違いなどの意 見分布を把握するには長時間と多大な労力を要する。ま た，分析の客観性を担保することも困難である.

そのような中，大量のテキストデータを分析する手法 としてテキストマイニングが注目を集めている. テキス トマイニングとは，テキストデータをコンピュータで定 量的に解析して有用な情報を抽出するためのさまざまな 
方法の総称であり, 同分析手法を用いることで大量のテ キストデータを統一的な視点から少ない労力で分析する ことが可能となるの.

PC に提出された意見に対してテキストマイニングを 実施した既存研究としては, 高レベル放射能廃棄物の地 層処分に対する 67 件の意見から一般市民が持つイメー ジの心理分析を行ったもの坊ある。一方，自由記述の テキストデータを用いた既往研究としては，限界自治体 の住民に対する生活質に関する選択式および自由記述式 のアンケート調査の結果から, 出現語の共起ネットワー クを描いたり，出現語の傾向と選択式の結果と組み合わ せたりすることによって, 生活質評価の構造を把握しよ うとしたもの ${ }^{8} や ，$ 東日本大震災時の帰宅行動に関する web アンケート調査の結果から, 出現語のクラスター分 析や対応分析を実施することによって帰宅行動を支えた 施設を明らかにしたもの 9などがある.しかし，近年見 られるようになってきた大規模 PC に対してテキストマ イニングを行い，提出された意見の論点を特定したり， 論点間の関係性を可視化しようとした研究は管見の限り 見当たらない.

そこで本研究では，大規模パブリックコメントに提出 された意見から主要な論点を把握し, 論点間の関係性を 可視化するための分析手法としてテキストマイニングの 有用性を検討寸るとともに, 問題点や課題を明らかにす ることを目的とする. 本研究の成果は, 大規模パブリッ クコメントにおいて，提出された意見から意見の全体像 を概観する手法の開発につながり, PC を導入した政策決 定プロセスの透明性の向上や提出された意見に基づく議 論の展開にも資すると考えられる.

\section{2. 研究方法}

\section{(1) 分析の対象}

本研究では，大規模 PC の一例として国家戦略室が実 施した「エネルギー・環境に関する選択肢に対する御意見 の募集」に提出された意見を分析の対象とする.「エネル ギー・環境に関する選択肢に対する御意見の募集」とは, エネルギー・環境に関する 3 つ選択肢(原発依存度を基 準に，(1)ゼロシナリオと(2)15 シナリオ，(3)20〜25 シナリ 才)を巡る国民的議論の一環として国家戦略室によって, 2012年7月 2 日〜 月 12 日の間に実施されたPCであり,

HP入力またはFAX，郵送によって受け付けられ，88,634 件の意見が寄せられた.

同 PCは「整理番号(ID)」と「個人・法人等」職業」年齢」 「性別」「ご意見の概要」御意見及びその理由」の 7 項目か ら構成されているが, 本研究では「年齢」と「性別」御意見 及びその理由」を分析に用いる. なお,「年齢」については,
具体的な年齢ではなく，10 代以下と $20 \sim 70$ 代，80 代以 上の 8 つ年代で示されているため, これ以降, 本稿で は「年代」と表記する. 提出された意見の中には, 複数人 の意見が 1 つ意見として提出されているものもあり， その場合，複数の年代や性別が記されている.

提出された膨大な意見の全文は，それらを集計した結 果とともに国家戦略室のウェブサイト上で公表されてい る. 公表されている集計結果は, 職業や年代など基本的 属性ごとの意見数と, 各意見をその内容によって「原子力 の安全確保と将来リスクの低減「エネルギー安全保障の 強化」地球温暖化問題解決への貢献」コストの抑制, 空 洞化防止」の 4 つの大な視点とさらに細かな 25 の論点 に分け，論点ごとに意見数を集計した結果である(表-1 参照).ただし， 25 に論点を分ける根拠となった $4 つ の$ 視 点は事前に有識者から提起された視点に基づいたもの ${ }^{10)}$ であり，提出された意見の内容を踏まえて設定された視 点ではなかった. 表-1の視点ごとの意見数の総数が提出 された意見数より多いことから意見をのべで集計してい ることがわかるが, これら 4 つの大きな視点から 25 の細 かな論点を定義した方法や, 各意見を論点に分類した基 準を含めその具体的な集計方法などは公表されていない． また，年代や性別による論点の集計など，属性による意 見の傾向や，論点間の関係性の違いなどの分析は行われ ていないようである.

\section{(2) 分析の枠組み}

本研究では, 前述したエネルギー・環境会議のPC 提出された全 88,634件の意見中の頻出上位語に対して主 成分分析とクラスター分析を実施することで同意見の論 点を特定し, 特定した各論点の出現件数を把握する. 特 定した論点については国家戦略室の結果 (表-1, 後掲の図 -1) と比較することによって, 分析手法の有効性について 検討する. また, ネットワーク分析の手法を援用してネ ットワークグラフを描くことで, 論点間の関係性の可視 化を試みる.なお, 各論点の出現件数については年代別, ネットワークグラフについては性別にもそれぞれ把握・ 可視化することで，属性による論点への言及の傾向の違 いを考察する.

なお，分析のための専用ソフトとしては，解析の簡便 性や汎用性を考慮して自然言語処理には $\mathrm{tm}^{11)}$, 多変量

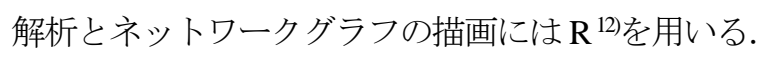

\section{(3) 分析データの前処理}

まず，「エネルギー・環境に関する選択肢に対する御意 見の募集」に提出された意見を国家戦略室のウェブサイ トより収集し, 次のような手順で分析のための前処理を 実施する.

(1)収集したすべての意見を合体した一つのテキストフ 
アイルを作成する．このとき，1つの意見を1つの集計 単位(段落)とし, 年代と性別でタグ付けを行う.また, 無記入のものや, 英数字または記号のみの意見は分析 対象から除外する. なお本研究で対象とするPCは，た とえば簡潔な表現や冗長な言い回しなど, 意見提出者 によって書き方が異なることが考えられる．そのため 本研究では, 語の出現頻度を回数ではなく段落, つま り各意見における出現の有無で把握する.

(2) 出現段落数の上位 1,000 語の名詞を抽出し, そのうち 一般とサ変接続, 複合名詞に分類された上位 150 語を 分析対象語とする.

\section{(4) 論点の特定}

本研究では, 前処理によって抽出した 150 語を用いて, 次のような手順で論点の特定を試みる.

(1) 対象語の出現・非出現を意見ごとに把握し, 分析意見 数 (対象段落数) $\times$ 対象150語のマトリックス (出現 : 1 , 非出現：0)を作成寸る.

(2) 作成したマトリックスに対して主成分分析を行い, 主 成分負荷量を求める.

(3) 得られた主成分負荷量に基づきクラスター分析を行 い, 対象語を分類する. このとき, クラスター数は, 後述するように解釈が可能な結果が得られた 20 とした. また, クラスター間距離はユークリッド平方距離で定 義し, 距離計算手法にはウォード法を用いる. なお, ここでは，対象語をグルーピングすることを目的にク
ラスター分析を行うため, 連鎖が起こりにくいとされ ているウォード法 ${ }^{14)}$ と, ウォード法で一般的に用いら れる非類似度係数であるユークリッド平方距離を用い る.

その上で，各クラスターに分類された語群がある論点 に関する意見の内容を表わすキーワードであるとみなし， 論点名の命名を試みる. 後述するように, 本研究では20 のうち17のクラスターについて論点を特定することがで きたため, これ以降の分析では17の論点を対象とする.

\section{(5) 各論点に言及している意見数の集計}

特定することができた論点について，それぞれのクラ スターに含まれる語が出現した段落数を集計する．この とき, 1 つの段落の中に同じクラスターに分類された語が 複数回出現しても, 論点の出現件数としては1件として集 計する. 一方, たとえば1つの段落の中に, 異なるクラス ターに分類された2種類の語が同時に出現した場合, 論点 の出現件数としてはのべ2件として集計する. なお, 本研 究で対象としている意見のそれぞれには，提出者の属性 も示されていることから，併せて年代別による集計およ び分析も行ってみる.このとき, 複数人から 1 つの意見が 提出されており, 複数の属性が含まれる意見は分析対象 から除外寸る。

\section{(6) 論点間の関係性の可視化}

最後に, 次のような手順で各論点の出現件数の多さを

表-1 国家戦略室が設定した $4 つ の$ 視点と 25 の論点とその集計結果 ${ }^{13)}$

\begin{tabular}{|c|c|c|c|}
\hline 視点 & 論点 & $\begin{array}{l}\text { 各論点に分類 } \\
\text { された意見数 }\end{array}$ & $\begin{array}{l}\text { 視点ごとの } \\
\text { 意見数 }\end{array}$ \\
\hline \multirow{10}{*}{$\begin{array}{c}\text { 「原子力の安全確保と } \\
\text { 将来リスクの低減」 }\end{array}$} & 1) 原子力安全に不安，事故原因・影響も不明，健康被害もある & 47,901 & \multirow{10}{*}{118,490} \\
\hline & (2) 核廃棄物は将来世代に負担を残す & 22,691 & \\
\hline & (3) 原子力開発は倫理的に適切ではない & 33,276 & \\
\hline & (4) 今脱原発か推進かを決められない, 決めるべきでない & 636 & \\
\hline & (5) 安全対策を強化することで, リスクを最少化できる & 2,172 & \\
\hline & (6) 時間とコストがかかる廃炉を着実に進めることが重要 & 8,070 & \\
\hline & (7) 安全を担う人材と技術が必要である & 1,838 & \\
\hline & (8) 原子力平和利用国としての責務を果たすべき & 257 & \\
\hline & (9) 国家安全保障のため核関連技術を保有すべき & 1,169 & \\
\hline & (10) 原発の不良債権化や立地地域への影響を懸念 & 480 & \\
\hline \multirow{6}{*}{$\begin{array}{l}\text { 「エネルギー安全保障 } \\
\text { の強化」 }\end{array}$} & (11) 再生可能エネルギーや新エネ開発こそ急ぐべき & 35,063 & \multirow{6}{*}{45,161} \\
\hline & (12) 国際エネルギー情勢を注視しいずれにも偏らず多様化を進めるべき & 904 & \\
\hline & (13) 化石燃料の，調達源の多様化，戦略的活用が重要 & 1,516 & \\
\hline & (14) 非化石電源である原子力発電が重要 & 1,073 & \\
\hline & (15) 電力の安定供給のためには原子力発電が必要 & 3,331 & \\
\hline & (16)今でも電気は足りている & 3,274 & \\
\hline \multirow{5}{*}{$\begin{array}{l}\text { 「地球温暖化問題解決 } \\
\text { 〜の貢献」 }\end{array}$} & (17) 温暖化対策にもっと積極的に取り組むべき & 3,528 & \multirow{5}{*}{4,047} \\
\hline & (18 温暖化対策は他国の動向を見極めつつ推進すべき & 53 & \\
\hline & (19) 温暖化対策は国外での実施に貢献すべき & 24 & \\
\hline & (20) 温暖化対策は重視する必要ない & 268 & \\
\hline & (21) 温暖化はしていない & 174 & \\
\hline \multirow{4}{*}{$\begin{array}{l}\text { 「コストの抑制, 空洞 } \\
\text { 化防止」 }\end{array}$} & 222 新産業や雇用創出の好機である & 3,756 & \multirow{4}{*}{8,603} \\
\hline & (22) 経済への影響を見極めながら, エネルギーシフトすべき & 842 & \\
\hline & (24) コストがあがり，経済に影響が出て，雇用が失われる & 3,609 & \\
\hline & (25) エネルギー多消費産業の構造転換が必要となる & 396 & \\
\hline
\end{tabular}


ノード(円)の大きさに，各論点が同じ意見中で言及され ている(以下，共起)多さをエッジ(線)の太さとしてネッ トワークグラフを描くことで，論点間の関係性の可視化 を試みる. なお，ここでは性別による分析を併せて行っ てみる。

(1) 各論点への言及の有無を段落ごとに把握し, 対象段落 数×特定することができた 17 の論点のマトリックス （出現：1, 非出現：0)を作成する.

(2) 作成したマトリックスに対して主成分分析を行い，主 成分負荷量を求める.

(3)得られた主成分負荷量に基づき論点間のユークリッ ド平方距離を求め, 同距離に関する対象論点 $\times$ 対象論 点のマトリックスを作成する.

(4)作成したユークリッド平方距離のマトリックスの固 有べクトルに基づき，ネットワークグラフのノードを 配置する．ここで固有ベクトルに基づく配置とは，構 造同值性の高いノード同士がより近くに配置されるこ とを意味する ${ }^{15}$. また構造同值とは，一組のノードの 間において，それらが持つ他のノードとの関係性が同 じであることを指す ${ }^{10}$. これらのことから，描かれる ネットワークグラフにおいては, 共起する傾向が高い
論点同士がノードとして近くに配置されることになる.

\section{3. 分析の結果}

\section{(1) 分析データの前処理}

前述した前処理を行った結果，まず，作成したテキス トファイルは 88,634(HP入力と FAX，郵送がそれぞれ

58,986 と 19,864，9,784) 段落であり, 出現段落数上位 1,000 語の名詞を含む段落は，84,915(HP入力と FAX, 郵送が それぞれ 58,904 と 17,961，8,050) 段落であった. 出現段落 数上位 1,000 語の名詞のうち, 本研究で対象とする一般と サ変接続，複合名詞に分類された語は 757 語であり, 出 現段落数の上位 150 語を分析対象語とした.

以上の手順によって対象とした 150 語が出現するのは 82,361 (HP入力と FAX，郵送がそれぞれ 58,189 と 16,710， 7,462)段落であった.

\section{(2) 論点の特定}

まず, 対象とした 150 語を 20 のクラスターに分類する ことで論点の特定を試みた．その結果を表-2に示す．表

表-2 論点を特定した結果と各論点の出現件数

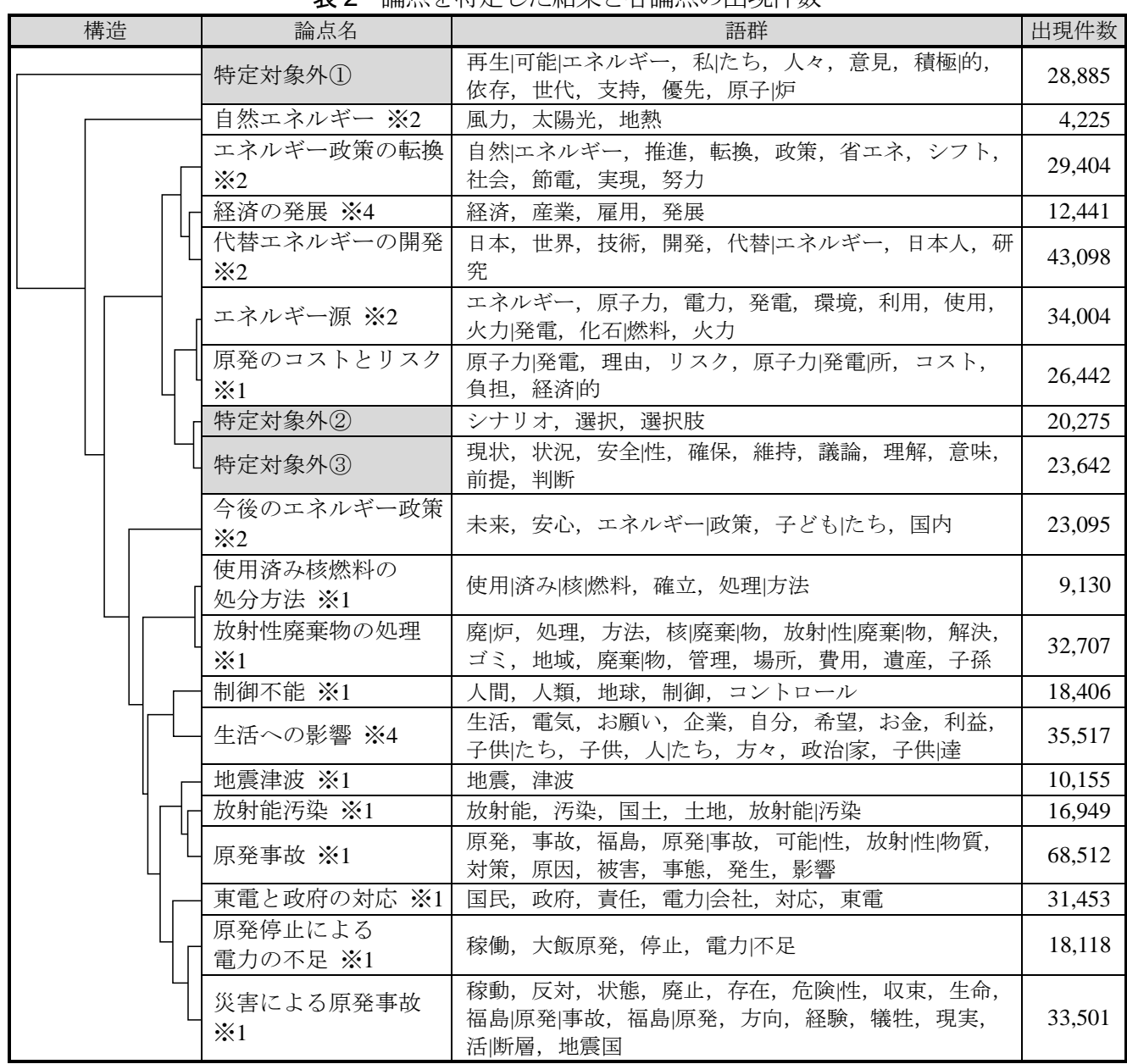

各論点に関連する視点 $(※ 1$ : 原子力の安全確保と将来リスクの低減, $※ 2:$ エネルギー安全保障の強化, $※ 3$ : 地球温暖化問題解決への貢献，※4：コストの抑制，空洞化防止） 
には，各論点に分類された語が出現した意見の出現件数 を併せて示している. 表における論点名」は, 各クラス ターに分類された語群から論点を特定することができた クラスターに対して筆者らが命名したものである. 多様 な種類の語を含み論点を特定することが困難であった 3 つのクラスターについては「特定対象外」とした。 また, 論点名の右に示した※番号は, 特定した論点が関連して いるであろう, 国家戦略室が設定した4つの視点を示し ている. 一方, 語の列において, 語の中に含まれている 縦棒は, その語が $\mathrm{tm}$ によって複合語に分類されたこと を表している.

表に示寸ように, 20 に分類したうち 17 のクラスターに ついて,「エネルギー政策の転換」や「原発のコストとリス ク」「放射性廃棄物の処理」などの論点名を命名すること ができた. なお，「特定対象外」としたクラスターには「私 たち」や「シナリオ」選択」議論」などの語が分類された. そのうち「特定対象外(1)は他のクラスターとの距離も遠 かった，特定することができた論点について，国家戦略 室が設定した視点と比較すると,「地球温暖化問題解決一 の貢献」を除く $3 つ の$ 視点に関連する論点を特定するこ とができた. 各論点の出現件数に着目すると, 「原発事故」 が 68,512 件で最も多く，それに「代替エネルギーの開発」 と「生活一の影響」がそれぞれ 43,098 件と 35,517件で続い た.

次に，上記の集計結果を，国家戦略室が4つの視点ご とに集計した結果とともに図-1に示寸. 図に示すように, 本研究と国家戦略室の集計結果を比較すると, 両者とも 出現件数の多い順に「原子力の安全確保と将来リスクの 低減」エネルギーの安全保障の強化」「コストの抑制, 空 洞化防止」であった. 各視点の出現件数の割合に着目寸る
$0 \%$

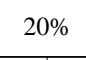

$40 \%$

$60 \%$

$80 \%$

$100 \%$

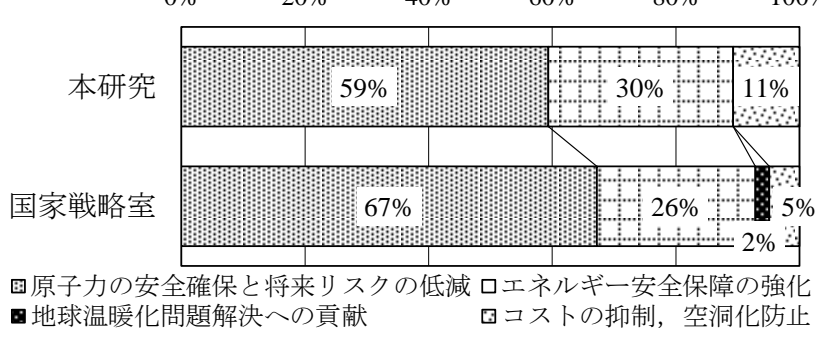

図-1 本研究と国家戦略室との集計結果の割合の比較

と, 本研究の集計結果は国家戦略室の集計結果に比べて 「原子力の安全確保と将来リスクの低減」の視点の割合が 低かったのに対して,「エネルギー安全保障の強化」「コ ストの抑制, 空洞化防止」の割合は高かった. なお，関連 する論点を特定できなかった「地球温暖化問題解決への 貢献ににつては, 国家戦略室の集計結果でも $2 \%$ と最も 少数派の視点であった.

続いて，各論点の出現件数に関する年代別のクロス集 計と, 集計結果に対して属性と各論点への言及の傾向と の間の相関関係の有無に関する判定を，調整残差 $\mathrm{R}$ 用 いて行った. 調整残差 Rは, クロス表で優位なセルを特 定するための統計量であり, 同值の絶対值が 1.96 以上と 2.58 以上の場合，それぞれ危険率 $5 \%$ と $1 \%$ 水淮で統計的 に出現件数が多い，あるいは少ないと判断することがで きる ${ }^{17}$. その結果を表-3に示す．表中の年代別各論点の 出現件数の行列において, 表の脚注に示すように, 黒色 と黒色の斜線, 白抜きで示したセルは, 危険率 $1 \%$ 末満, 灰色と灰色の斜線のセルは $5 \%$ 末満で有意に大きかった (あるいは小さかった)ことを示している.また表には, 各論点と年代別の出現件数の合計值を併せて示している. 表に示寸ように, 各論点への言及の傾向には年代によ

表-3 年代別の各論点の出現段落数

\begin{tabular}{|c|c|c|c|c|c|c|c|c|c|c|c|c|c|c|c|c|c|c|}
\hline & $\begin{array}{l}\text { 自 } \\
\text { 然 } \\
\text { エ } \\
\text { ネ } \\
\text { ル } \\
\text { ギ } \\
\text { I }\end{array}$ & $\begin{array}{l}\text { エ } \\
\text { ネ } \\
\text { ル } \\
\text { ギ } \\
\text { I } \\
\text { 政 } \\
\text { 策 } \\
の \\
\text { 転 } \\
\text { 換 }\end{array}$ & $\begin{array}{l}\text { 経 } \\
\text { 済 } \\
\text { の } \\
\text { 発 } \\
\text { 展 }\end{array}$ & $\begin{array}{l}\text { 代 } \\
\text { 替 } \\
\text { エ } \\
\text { ネ } \\
\text { ル } \\
\text { ギ } \\
\text { l } \\
\text { の } \\
\text { 開 } \\
\text { 発 } \\
\end{array}$ & $\begin{array}{l}\text { エ } \\
\text { ネ } \\
\text { ル } \\
\text { ギ } \\
\text { l } \\
\text { 源 }\end{array}$ & $\begin{array}{l}\text { 原 } \\
\text { 発 } \\
\text { の } \\
\text { コ } \\
\text { ス } \\
\text { ト } \\
\text { と } \\
\text { リ } \\
\text { ス } \\
\text { ク }\end{array}$ & $\begin{array}{l}\text { 今 } \\
\text { 後 } \\
\text { の } \\
\text { エ } \\
\text { ネ } \\
\text { ル } \\
\text { ギ } \\
\text { l } \\
\text { 政 } \\
\text { 策 }\end{array}$ & $\begin{array}{r}\text { 処使 } \\
\text { 分用 } \\
\text { 方済 } \\
\text { 法 } \\
\text { 核 } \\
\text { 燃 } \\
\text { 料 } \\
\text { の }\end{array}$ & $\begin{array}{l}\text { 放 } \\
\text { 射 } \\
\text { 性 } \\
\text { 廃 } \\
\text { 衰 } \\
\text { 物 } \\
\text { の } \\
\text { 処 } \\
\text { 理 }\end{array}$ & $\begin{array}{l}\text { 制 } \\
\text { 御 } \\
\text { 不 } \\
\text { 能 }\end{array}$ & $\begin{array}{l}\text { 生 } \\
\text { 活 } \\
\text { の } \\
\text { の } \\
\text { 影 } \\
\text { 響 }\end{array}$ & $\begin{array}{l}\text { 地 } \\
\text { 震 } \\
\text { 津 } \\
\text { 波 }\end{array}$ & $\begin{array}{l}\text { 放 } \\
\text { 射 } \\
\text { 能 } \\
\text { 污 } \\
\text { 染 }\end{array}$ & $\begin{array}{l}\text { 原 } \\
\text { 発 } \\
\text { 事 } \\
\text { 故 }\end{array}$ & $\begin{array}{l}\text { 東 } \\
\text { 電 } \\
⿱ \\
\text { 政 } \\
\text { 府 } \\
の \\
\text { 対 } \\
\text { 応 }\end{array}$ & $\begin{array}{c}\text { 電原 } \\
\text { 力発 } \\
\text { 不停 } \\
\text { 足止 } \\
\text { に } \\
\text { よ } \\
\text { る }\end{array}$ & $\begin{array}{l}\text { 災 } \\
\text { 害 } \\
\text { に } \\
\text { よ } \\
\text { る } \\
\text { 原 } \\
\text { 発 } \\
\text { 事 } \\
\text { 故 }\end{array}$ & $\begin{array}{l}\text { 合 } \\
\text { 計 }\end{array}$ \\
\hline 10代以下 & 51 & Whes & 缩 & 493 & 399 & 310 & 333 & 徨 & 晿 & 将晿 & 545 & 134 & 235 & 1199 & Wuthe & 211 & 桨多齐 & 536 \\
\hline 20代 & 275 & 2015 & 150 & 2832 & 2495 & 1996 & 1715 & 约 & 行 & VI⿰彳 & 2670 & 620 & 後新 & 4871 & 2088 & 1252 & 徐行 & 2987 \\
\hline 30代 & 899 & 6550 & 2679 & 9367 & 7650 & 6175 & 5620 & Thus & 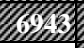 & 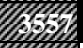 & 9057 & 得魚 & 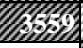 & 1484 & Ty & 4146 & Mini & 98303 \\
\hline 40代 & 1016 & 7262 & 3201 & 10867 & 8604 & 7255 & 5630 & 2332 & 8286 & 缩後 & 8722 & 2623 & 4120 & 约的 & 7858 & 4786 & 8170 & 111345 \\
\hline 50 代 & 825 & 5751 & 2658 & 8696 & 6662 & 5245 & 4488 & 2027 & 6697 & 3786 & 䋾约 & 2024 & 3377 & 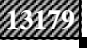 & 6282 & 3518 & 6858 & 8839 \\
\hline 60代 & 742 & 4923 & 2033 & 7325 & 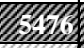 & 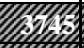 & 得姼 & 1817 & 5970 & 3902 & 邪 & 1846 & 3068 & 11728 & 5581 & 药新 & 6227 & 76310 \\
\hline 70 代 & 266 & 1572 & 606 & 2229 & 1687 & 物 & 位 & 547 & 1737 & 1238 & "19 & 519 & 975 & 3934 & 1648 & 药物 & 1940 & $2341 \mathrm{C}$ \\
\hline 80 代以上 & 40 & 297 & Wha & 476 & 332 & W璆 & 246 & Wy & 318 & 234 & 346 & 96 & 206 & 964 & 307 & Wus: & 402 & 4771 \\
\hline 合計 & 4114 & 28642 & 12158 & 42285 & 33305 & 25961 & 22534 & 8887 & 32116 & 18083 & 34835 & 9926 & 16573 & 67009 & 30773 & 17784 & 32797 & 437782 \\
\hline & & & & & & & & $2.58>\mathrm{R} \geq 1.96$ & \multicolumn{2}{|c|}{ 調整残差 $\mathrm{R} \geq 2.58$} & \multicolumn{2}{|c|}{ 出現件数 } & \multicolumn{3}{|c|}{$-1.96 \leq \mathrm{R}<-2.58$} & 出現件数 & 徏的的 & \\
\hline
\end{tabular}


って違いが見られた．たとえば「放射性廃棄物の処理」や 「制御不能「「災害による原発事故」については高い年代ほ ど，「今後のエネルギー政策」や「原発のコストとリスク」 「生活への影響」は低い年代ほじ多く言及する傾向が見ら れた. 一方で,「エネルギー政策の転換」や「代替エネルギ 一の開発」については, 年代による差はほとんど見られな かった.

\section{（3）論点間の関係性の可視化}

最後に, 各論点の出現件数をノードの大きさに, 他の 論点との間の共起の多さをエッジの太さとして, ネット ワークグラフを描いた. その結果を図-2に示す. 図にお いて, 各論点について他の論点と共起する数が 10,000段 落以上の場合にのみエッジを描いており，他のノードと エッジを持たなかった「自然エネルギー」と「使用済み核 燃料の処分方法」地震津波」を除いた 14 の論点のみを示 した.

図に示すように，出現件数が多かった論点に着目する と,「原発事故」の周辺には「災害による原発事故」や「放射 性廃棄物の処理」などが,「代替エネルギーの開発」の周辺 には「エネルギー政策の転換」や「経済の発展」など,「生活

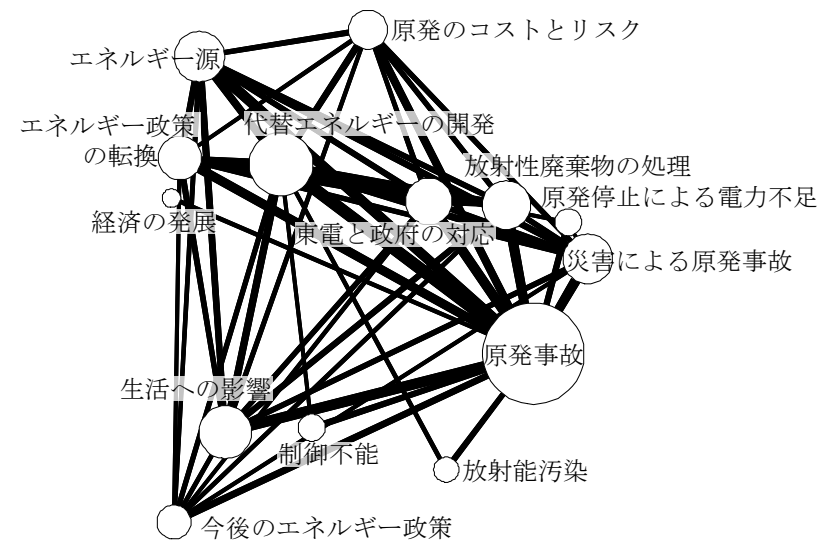

図-2 論点間の関係性
への影響」の周辺には「今後のエネルギー政策」の論点が 配置された. 表-2 に示した樹形図の構造と比較すると, クラスター間の距離が近い論点同士が近くに配置されて いた.

同様の分析を性別に行った結果を図-3に示す．ここで は，論点が同時に言及される数がそれぞれの平均值以上 の場合にのみエッジを描いている，また，ネットワーク の構造を表す指標である密度と集中度を男女それぞれで 求めた結果, 密度が 0.5128 と 0.4551 , 集中度が 6.205 と 6.769 であった. ここで密度とは, ネットワークにおいて理論 的に存在可能なうちどの程度のエッジが実際に存在して いるかを，集中度とは，グラフにおいて中心性が高いノ 一ドにエッジが集中している程度を表寸指標 ${ }^{16) て ゙ あ る . ~}$ つまり本研究では, 密度が高いとは各意見中で言及され る論点が多いことを, 集中度が高いとは一つの意見の中 で中心性の高い論点と共起する論点が一部の論点に集中 していることを, 低いとは, 多くの論点が共起すること を意味する.

図に示すようにまず，「制御不能」と放射能污染「原発 停止による電力不足」は男女ともに, さらに男性に関して は「今後のエネルギー政策」の論点が,「原発事故」とのみ エッジが繋がっていた．また，男女で論点の配置に違い が見られた. たとえば，男性は「原発事故」の周辺に「放射 性廃棄物の処理」や「原発停止による電力不足」などが配 置されているのに対して，女性はこれらの論点は比較的 離れて、「放射能污染」が近くに配置されていた。

\section{4. 考察}

\section{(1) 論点の特定}

まず，「エネルギー・環境に関する選択肢に対する御意 見の募集」に対して提出された意見から論点の特定を試 みた結果, 表-2に示したように 17 の論点を特定すること

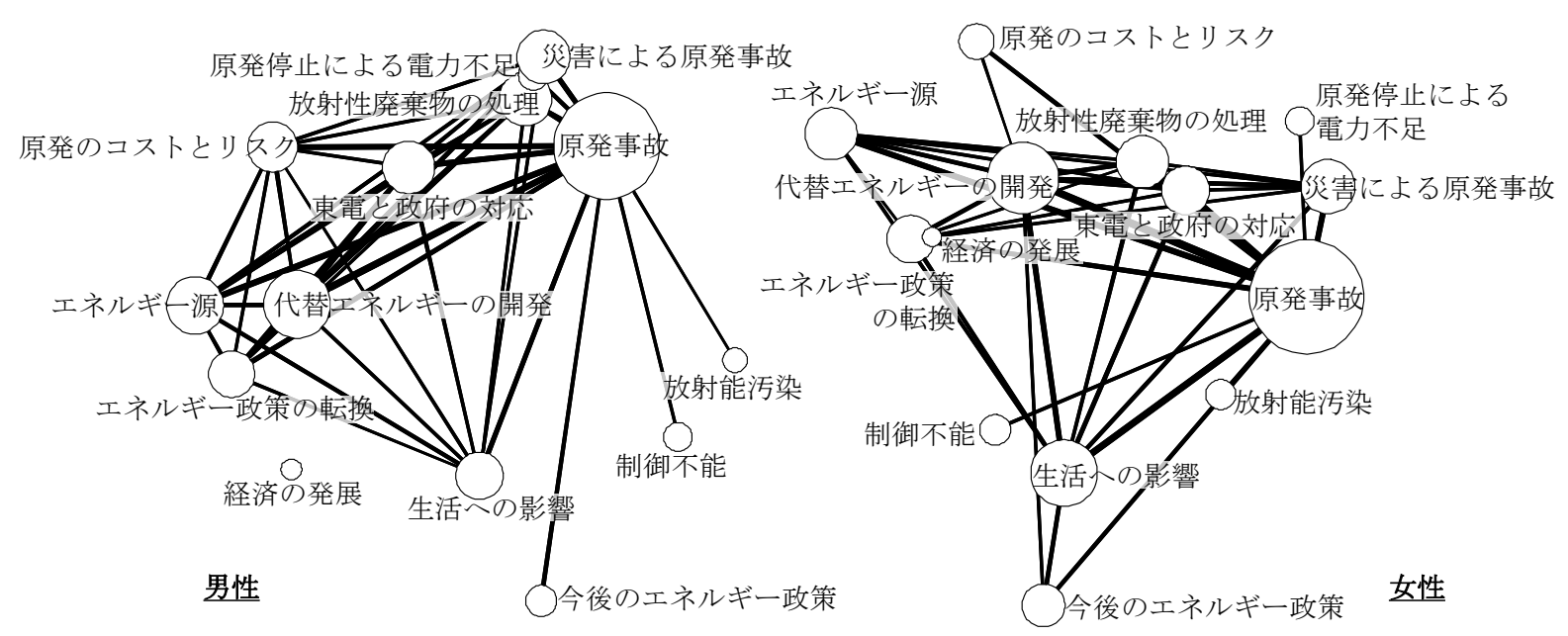

図-3 性別に把握した論点間の関係性 
ができた.これに対して「特定対象外」としたクラスター には，「シナリオ」や「選択」議論」「意味」など，論点とは 直接関係ないと考えらえる語を含む $2 つ$ (「特定対象外(2), (3) と多様な語が含むもの (「特定対象外(1)」)が 1 つあっ た.このうち，「特定対象外(1)」したクラスターに関し ては, 他のクラスターとの距離が最も遠く, かつ, 各意 見に含まれた語の間の出現の有無の相関係数が他に比心゙ て極端に高かった：これは，同一意見中で言及されるこ とが極端に多い組み合わせの語からクラスターが形成さ れたことを意味しており，類似した意見が大量に提出さ れた可能性を示唆している.

また，特定することができた論点と表-1に示した国家 戦略室が設定した 4 つ視点とを比べると, 「原子力の安 全確保と将来リスクの低減」の視点では 10 の論点を, 「エ

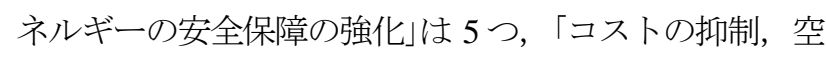
洞化防止」では 2 つ関連する論点を特定することがで きた. しかしその一方で「地球温暖化問題解決への貢献」 の視点に関わる論点は抽出することができなかった．国 家戦略室の集計結果においても同視点の意見数の割合は $2 \%$ と少数であったように, 提出された意見の中で地球温 暖化に関連寸る論点は言及されることが比較的少なかっ たと考えられる.そのため関連する語の出現頻度が低く, 頻出上位語を分析に用いた本研究では対象から外れたこ とが直接的な原因として考えられる.

次に, 各論点の出現件数を年代別に把握し, 集計結果 に対して調整残差を用いた判定を行った結果, 年代によ る論点への言及傾向の違いを把握することができた，具 体的には, 高い年代は「放射性廃棄物の処理」や「災害によ る原発事故」など事故や災害に関する論点に言及する傾 向があるのに対して，低い年代は「今後のエネルギー政 策」や「生活への影響」など実生活に関連する論点に言及 する傾向があることがわかった.

\section{（2）論点間の関係性の可視化}

最後に，論点間の関係性の可視化を試みた図-2 と図-3 から, 次のようなことが考察できる.まず，全体の結果 である図-2から, 出現件数が最も多かった「原発事故」の 周辺には「災害による原発事故」や「放射性廃棄物の処理」 など配置されており，東日本大震災における原発事故や それによる放射性廃棄物，放射能污染などを意識した意 見が多くあったことが推察される.また,「エネルギー源」 や「エネルギー政策の転換」「代替エネルギーの開発」「経 済の発展」の論点は互いに距離が近く, 代替エネルギーの 開発を経済発展の機会と考える意見が多かったことが考 えられる。

一方，図-3に示したように，男性は女性と比べてネッ トワークの密度が高く，集中度が低かった。このことか ら男性は複数の論点に言及するのに対して，女性は比較
的限定した論点に言及する傾向があることが推察される. さらに，「原発事故」の周辺に配置された論点に着目寸る と, 男性は「放射性廃棄物の処理」や「原発停止による電力 不足」が，女性は「放射能污染」が配置されており，性別に よって懸念事項が異なる可能性が示唆される.

なお，図-2 と図-3 ともに表-2に示したクラスター分析 の結果において距離が近い論点同士が近くに配置された が，これは，語の出現パターンによって語を分類して論 点を特定し, 同論点の共起によってネットワークグラフ を描いていることから，ある程度当然の結果と言える。

ただし表-2では, 樹形図としてしか論点間の関係性を読 み取ることができなかったが，論点の共起の傾向に基づ く論点間の距離を用いてネットワークグラフに描くこと で，関係性をより視覚的に示すことができた．また，年 代別の論点ごとの集計と同様, これらネットワークグラ フを属性別に描画することで, 属性による言及傾向の違 いをより詳細に分析できる可能性を示すことができた.

\section{5. おわりに}

本研究では，国家戦略室が 2012 年に実施した「エネル ギー・環境に関する選択肢に対する御意見の募集」を事例 として，大規模パブリックコメントに提出された意見か ら主要な論点を把握し, 論点間の関係性を可視化するた めの分析手法としてテキストマイニングの有用性を検討 するとともに，問題点や課題を明らかにすることを試み た. その結果, 次のような知見を得ることができた.

まず，提出された意見から「エネルギー政策の転換」や 「放射性廃棄物の処理」「生活への影響」などの17の論点を 特定することができた．これら特定することができた論 点は, 国家戦略室が設定した 4 つの視点のうち最も割合 が低かった「地球温暖化問題解決一の貢献」を除く 3 つに 対応しており，ある程度論点を特定することができたも のと考えられる. 同時に, 意見提出者の年代別に各論点 の出現件数を集計し, 調整残差を用いた判定を行うこと によって，言及している論点の年代による傾向の違いを 把握することができた. さらに，各論点の出現件数の多 さをノードの大きさに, 論点間の共起の多さをエッジの 太さとしてネットワークグラフを描くことによって, 論 点間の関係性を可視化することに成功した. 論点の属性 別の集計と論点間の関係性に関しては，本稿で示した年 代・性別以外の属性で分析することも可能であり，PCに 提出された意見から，より詳細に住民意見を把握できる 可能性も示寸ことができたと考えられる.

以上のように，本研究ではテキストマイニングを用い たことで分析の客観性を担保しつつ属性別に意見数を集 計したり，属性による言及傾向の違いを把握したりする 
ことが可能になった.このような論点ごとに意見数を集 計した根拠の提示や，属性による論点への言及の傾向の 把握は，国家戦略室が公表した集計結果には見られなか ったものである. 本稿では一例として年代別の集計結果 を示したが，職業や性別によって集計することも，たと えば複数の属性の組み合わせによる, より詳細な分析を 行うことも可能である.

次に, 大規模 PC に対してテキストマイニングを実施 寸る際の問題点や課題として, 本研究では次の 5 点が明

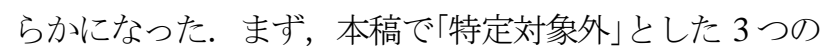
うち，1つは極端に類似した意見が大量に提出されたこ とによって形成されたクラスターであると考えられた. 大規模PCではこのような意見群がある可能性に留意し, その扱いを慎重に検討する必要がある. 2 点目として, 国家戦略室が設定したうち「地球温暖化問題解決一の貢 献」の視点に関連する論点を特定することができなかっ たが，これは同視点に関連する語の出現頻度が低く本研 究では分析対象から外れたことが原因として考えられた ただし，単純に分析対象語を増やしても，クラスターや 関係性を可視化した結果が複雑になり，解釈が困難にな る可能性が高い，比較的言及の少ない論点を特定できる 対象語を客観的に抽出する手法を検討していく必要があ る. 3 点目として, 本研究では約 9 万件の意見を分析対 象としたが，より大規模あるいは比較的小規模な PC に ついても同様な分析を実施して，分析対象の規模に対す る本研究の分析手法の妥当性を検討する必要がある. 4 点目として, 本研究では語の出現頻度を段落で集計した が，たとえば文や回数を単位として分析を行うことも可 能であることから, 分析単位による結果の違いを比較・ 検討することも必要である. 5 点目として，本研究では 大規模な PC に対して提出された意見からまず把握する べき論点や言及の多い論点，属性による違いなど大まか な全体像の把握を試みたが，たとえば賛成と反対のよう な，意見の方向性を把握することはできていない，これ らは単純な賛否だけでなく, 条件付き賛成・反対やその 理由など, 複雑な構造を持つと考えられるが, 次の段階 として，これらを把握できるような手法を検討していく ことも必要であろう。具体的な方法としては，たとえば 出現語の傾向によって提出された意見を分類し, 分類し た意見群を分析していくような方法や，本研究では名詞 に分類されたうちの一般とサ変接続, 複合名詞のみを対 象としたが, それ以外の動詞や形容詞などを用いた分析， 係り受け解析などが考えられる，また，今回対象とした 国家戦略室による「エネルギー・環境に関する選択肢に対 する御意見の募集」では, 自由記述による意見の概要と意 見およびその理由を求める形式であったが，たとえばプ ルダウン形式でシナリオを選択し，その理由や意見を記 述するような形の PC であれば，選択したシナリオ別の
論点や意見の相違をより詳細に分析することができると 考えられる. シナリオ別の分析やその結果を比較するこ とによって，賛成・反対意見それぞれに出現する語の違 いや傾向など，意見の方向性をテキストマイニングによ って把握するための糸口が見つけられるのではないかと 考える. 加えて, 日本語は語尾の変化が複雑であり, 提 出された意見のテキストデータのみから意見の方向性を 的確に把握することが困難であると考えられるが，本研 究で提案した分析手法を英語や中国語などの言語に適用 し，検討することで，手法を発展させることも可能であ ろう.

以上のような課題を残したものの, 本研究の成果は大 規模 PC に提出された意見から意見の全体像を概観する ための分析手法の開発につながるものと考えられる.

\section{参考文献}

1) 山田久美子, 柳下正治: 我が国の気候変動政策における意 思決定プロセスーの市民関与の発展, 環境科学会誌, Vol.24, No.5, pp.422-439, 2011.

2）岩田元一: 都道府県の環境基本計画策定に際してのパ ブリックコメントに関する一考察, 日本社会情報学会 全国大会研究発表論文集, Vol.21, No.0, pp.62-65, 2006.

3) 加藤博・他 : 公共財としての庭園の保全および利活用 に対するパブリックコメントの現状, ランドスケープ 研究, Vol.74, No.5, pp.805-810, 2011.

4) 宮沢栄次 : 第三次環境基本計画について〜パブリック コメントで論点を探る(その 1), 社会イノベーション 研究, Vol.2, No.2, pp.91-108, 2007.

5) 宮沢栄次 : 第三次環境基本計画について〜パブリック コメントで論点を探る(その 2), 社会イノベーション 研究, Vol.3, No.2, pp.91-108, 2008.

6) 松村真宏, 三浦麻子: 人文・社会科学のためのテキス トマイニング, p.1, 誠信書房, 2009.

7) KUGO, A., et al: Text Mining Analysis of Public Comments Regarding High-level Radioactive Waste Disposal, Journal of NUCLEAR SCIENCE and TECHNOLOGY, Vol. 42, No. 9, pp.755-767, 2005.

8）塚田伸也・他 : 自由記述デー夕に着目した限界自治体にお ける生活質評価に関する分析一群馬県南牧村を対象とし て一, 日本建築学会計画系論文集, Vol.80, No.708, pp.361-368, 2015.

9) 伊藤香織・他 : 首都圈における震災時帰宅立ち寄り行動の 実証研究一東日本大震災に関する webアンケート調查に基 づく分析一, 都市計画論文集, Vol.48, No.3, pp.873-878, 2013.

10) 国家戦略室: 一政策一革新的エネルギー・環境戦略一 エネルギー環境会議話そう“エネルギーと環境のみら い”エネルギーの選択を行うに当たって重要となる 4 $つ の$ 視点 < www.cas.go.jp/jp/seisaku/npu/policy09/archiv ee01.html>, 2013-10-24 参照.

11）松村真宏, 三浦麻子: TTM:TinyTextMiner $\beta$ version, $<\mathrm{http}: / / \mathrm{mtmr} . j \mathrm{p} / \mathrm{ttm} />$, 2010-11-05 参照.

12) Institute for Statistics and Mathematics : The R Project for Statistical Computing, < http://www.r-project.org/ >, 
2010-12-28 参照.

13) 国家戦略室: 一政策一革新的エネルギー・環境戦略一 エネルギー環境会議＜www.cas.go.jp/jp/seisaku/npu/ policy09/archive01.html >, 2013-10-24 参照.

14) 柳井久江：エクセル統計 一実用多変量解析編一, pp.115-132, オーエムエス出版, 2005.

15) 鈴木努：Rで学ぶデータサイエンス 8 ネットワーク 分析, pp.145-158, 共立出版, 2009 .
16) 安田雪: 実践ネットワーク分析 関係を解く理論と技 法, pp.78-82, pp.96-97, 新曜社, 2001.

17）菅民郎：すべてがわかるアンケートデータの分析, pp.137-139, 現代数学社, 1998.

\title{
A STUDY ON UTILITY OF TEXT MINING FOR IDENTIFYING SUBSTANTIVE ISSUES IN LARGE-SCALE PUBLIC COMMENTS
}

(2015.7.27 受付)

\author{
Asako IWAMI, Tomoki MIYASHITA, and Shinji IDE
}

In this study, the authors tried to examine the utility and to clarify the problems of text mining for identifying substantive issues and visualizing relationship among the issues in large-scale public comments. As the result of case study with submitted comments of the "public comment for choices on energy and the environment" implemented by National Policy Unit in 2012, it was possible to illustrate the utility of text mining by identifying 17 issues such as "shift of energy policy", "disposal of radioactive waste", and so forth, as well as to visualize relationship among the issues by drawing network graphs. It was also possible to clarify the problems such as the existence of a large amount of comments with similar contents, and necessity of developing an objective word selection method for identifying the issues being mentioned less frequently. 